\title{
List of contributors
}

Camilla Adang (PhD, Radboud University Nijmegen) is Professor of Islamic Studies at Tel Aviv University. Her main fields of research are the history of Islamic thought in al-Andalus, the Zāhirī school in the Islamic West in general, and the legal, theological and political thought of Ibn Ḥazm of Córdoba in particular. Additional research foci are social and intellectual encounters between Muslims and Jews in the Middle Ages and the Ottoman period and Arabic translations of the Bible and biblical materials. She is the author of Muslim Writers on Judaism and the Hebrew Bible. From Ibn Rabban to Ibn Hazm (Brill, 1996); and, with Sabine Schmidtke, Muslim Perceptions and Receptions of the Bible: Texts and Studies (Lockwood Press, 2019). She also co-edited several volumes, among them Ibn Hazm of Cordoba. The Life and Works of a Controversial Thinker (Brill, 2013), Accusations of Unbelief in Islam. A Diachronic Perspective on Takfï (Brill, 2015), and Islam at 250. Studies in Memory of G.H.A. Juynboll (Brill, 2020). Her most recent publications analyse a series of texts from the fatwā collection of the 15th-century Moroccan scholar al-Wansharīsī.

Zohra Azgal is a PhD student at the Department of Historical and Philological Studies of the École Pratique des Hautes Études, Université PSL (Paris Sciences et Lettres), where she is preparing her thesis under the supervision of Professor Nuria de Castilla. She holds a B.A. in Arabic Studies from INALCO (Paris) and a M.A. in Islamology and Qur'ānic Studies from EPHE (Paris). She also holds several ljāzāt in Islamic Studies. Her research field focuses on the history of the transmission of the Qur'ān and the teaching of qirā'ät in the Middle Ages with special attention to the production of teaching manuals. Her research works across and in between the disciplines of Codicology, Philology, History and Qur'ānic studies.

José Bellver (PhD, University of Barcelona) is a research associate at the ERC project The Origin and Early Development of Philosophy in tenth-century al-Andalus: the impact of ill-defined materials and channels of transmission (ERC 2016, AdG 740618), conducted by Godefroid de Callataÿ at the University of Louvain. Bellver is currently preparing a monograph on the Andalusī theologian and mystic Ibn Masarra. His primary research interest focuses on the intellectual history of Islam, particularly on the fields of Șūfism, philosophy, kalām and history of science in al-Andalus. Bellver has held a Beatriu de Pinós postdoctoral position funded by the Catalan Government at the Theology Department of Boston College, a Ramón y Cajal research position at the Department for the History of Philosophy at the University of Barcelona, and has been research associate at the Universität Würzburg and the Bayerische Akademie der Wissenschaften in Munich. In the field of Andalusī Șūfism, Bellver has devoted research to the 6th/12th and 7th/13th centuries, and particularly to Ibn Barrajān and his disciples. He has published in the journals Arabica, Journal of the American Oriental Society, and Al-Qanțara among others, and contributes on Andalusī Șūfism to Encyclopaedia of Islam, THREE.

Philip Bockholt (PhD, Freie Universität Berlin) is currently research associate at the Institute of Oriental Studies, Leipzig University. He received his PhD in Islamic Studies in 2018 after studying History and Islamic Studies in Germany (Bochum, Münster, and Berlin) and the Middle East (Jerusalem, Cairo, Tehran, and Istanbul). In his PhD thesis, he examines the historiography in 
Iran of early Șafavid times (16th century), and provides the analysis of a major historiographical work of that period, Khvāndamīr's Habīb al-siyar. In 2019 he was awarded the Annemarie Schimmel Prize for Islamic Studies and an Honourable Mention of the S.I.E. European Award for Iranian Studies. Furthermore, in 2020 he received the Classical Islamic World Book Prize of Gorgias Press. A number of research fellowships led him to Saint Petersburg (State University), Madrid (CSIC), and Jerusalem (Hebrew University). At the moment, he is working on a project on translations from Arabic and Persian into Ottoman Turkish in the Eastern Mediterranean and beyond from around $1350-1750$.

Umberto Bongianino (PhD, University of Oxford) is Departmental Lecturer in Islamic Art and Architecture at the Khalili Research Centre, University of Oxford. He is principally interested in the architecture and material culture of the Islamic dynasties that ruled across the medieval Mediterranean between the 9th century and the 13th century. His studies have focused on a number of topics, including the Islamic components of Norman Sicilian art, ceramic production and trade in Fāțimid Egypt and Syria, Fāțimid architecture and archaeology in Cairo, Tunisia, and Libya (Ajdabiya), Arabic epigraphy and palaeography in the medieval Maghrib and al-Andalus. He is currently writing a book on the manuscript tradition of the Islamic West (10th-12th centuries).

Giovanna Calasso is a former Professor of History of Arab-Islamic Civilization in the Department of Oriental Studies at Sapienza University, Rome, where she taught until November 2016. Her research interests mainly focus on historical-religious and cultural issues of the Islamic Middle Ages in the perspective of historical anthropology. Religious traditions and hadīth literature, urban foundation narratives and representations of the city in medieval Arabic historical and geographical literature have been her earlier areas of interest. The theme of Islamization processes in the literary field, specifically concerning Persian epic poems, has been followed by studies on the notion of conversion to Islam and the different forms of individual religious experience, documented in biographical and hagiographical texts as well as in travelogues, a contribution to the European research project Individual and Society in the Mediterranean Muslim World (1996-2001). Several publications on Muslim travel literature, as a source for the history and mentalities of medieval Islamic societies, led her to exploring the binary categorization dār al-islām/dār al-harb in a wide range of sources and to the editing of a collective book on the topic (Dār al-islām/dār al-ḥarb. Territories, People, Identities, Brill, 2017). Among her latest publications are "A Wondrous Past, a Dangerous Present: the Egyptian Temple of Akhmīm and the Martorana Church in Palermo, as Seen through Ibn Jubayr's Travelogue" (The Medieval Globe, 2019), and the forthcoming "The Past before their own Past. Notes on Time, Otherness and the Monumental Remains of pre-Islamic Civilizations as seen by medieval Muslim authors" (in: L. Capezzone, ed., Before Archaeology).

Víctor de Castro León (PhD, University of Salamanca). He is currently researcher in the Project Mediterranean Nautical Cartography in Arabic and Ottoman Turkish: Islands or Gateways of Knowledge in the Sea of Transcultural and Translinguistic Translation Processes?, directed by S. Brentjes, Max Planck Institute for the History of Science, Department III, Berlin. He has been researcher in the project Practicing knowledge in Islamic societies and their neighbours (funded by the Alexander von Humboldt Foundation, IP M. Fierro, Anneliese Maier Award 2014) and a team member of the Research Project Local contexts and global dynamics: al-Andalus 
and the Maghreb in the Islamic East (FF12016-78878-R AEI/FEDER UE). His research focuses on Andalusi historiography, the history of Nașrid kingdom of Granada (13th-15th centuries) and the intellectual production of the Islamic West. Among his latest publications is "Ibn al-Hațīb, cronista oficial de la dinastía nazarí: teoría y práctica política” (in: V. Lamazou-Duplan, ed., Écritures du pouvoir, Ausonius, 2019).

Maribel Fierro (PhD, Universidad Complutense) is Research Professor at the Institute of Languages and Cultures of the Mediterranean, Spanish National Research Council (CSIC). She has worked and published on the political, religious and intellectual history of al-Andalus and the Islamic West, on Islamic law, on the construction of orthodoxy and on violence and its representation in Medieval Arabic sources. Among her publications are Abd al-Rahman III: The first Cordoban caliph (Oneworld, 2005), The Almohad revolution. Politics and religion in the Islamic West during the twelfth-thirteenth centuries (Ashgate, 2012), and 'Abd al-Mu'min, the first Almohad caliph (forthcoming). She is the editor of volume 2 of The Western Islamic world, eleventh-eighteenth centuries of the The New Cambridge History of Islam (Cambridge University Press, 2010), Orthodoxy and heresy in Islam (Routledge, 2013), and Routledge Handbook on Muslim Iberia (Routledge, 2020). She has co-edited The legal status of dimmi-s in the Islamic West (Brepols, 2013), and Accusations of Unbelief in Islam. A Diachronic Perspective on Takfir (Brill, 2015).

Teresa Garulo (PhD, Complutense University) is Professor of Arabic language and literature, at the Department of Arabic and Islamic Studies (now Lingüística General, Estudios Árabes, Hebreos y de Asia Oriental = General Linguistics and Oriental Studies), Complutense University of Madrid. After a first approach to Arabic linguistics and Arabic loanwords in Spanish (Los arabismos en el léxico andalus (según los datos del «Atlas Lingüístico y Etnográfico de Andalucía»), Instituto Hispano-Árabe de Cultura, 1983), her work focuses on Arabic Literature from alAndalus (La literatura de al-Andalus durante el siglo XI, Hiperión, 1998), some of whose poets she has studied and translated (al-Ruṣāfĩ of Valencia; Ibn Sahl of Seville) and edited (Ibn Șāra al-Shantarīn̄i Abū Tammām b. Rabāḥ of Calatrava), as well as the poetry written by Andalusi women (Dīwān de las poetisas de al-Andalus, Hiperión, 1986). Her interest in Arabic treatises on love brought her to study and translate the Kitäb al-Muwashshā, by the Baghdadi man of letters al-Washshā' (d. 325 H/937 CE) (El libro del brocado, Alfaguara, 1990). More recently, humor and obscene poetry had attracted her attention and she has written some papers on these topics as they appear in works describing al-Andalus (Ibn Sa'īd al-Maghribī, al-Maqqarī), but also in poetic anthologies written in the Middle East (Ibn al-Mu'tazz). Another field of her interest is the strophic poetry of al-Andalus and its migration to the East.

Adday Hernández López (PhD, Complutense University) is Postdoctoral researcher Juan de la Cierva-Incorporación (IJCl-2017-31351) at the Institute of Languages and Cultures of the Mediterranean, CSIC. She specializes in Islamic law in the pre-modern Islamic West (economic legal doctrines and practices, religious minorities), in the intellectual history in the same area (circulation of texts and ideas), and in the Arabic literature of the Horn of Africa. She has contributed to three research projects, two of them funded by the European Research Council (KOHEPOCU: Knowledge, Heresy and Political Culture in the Islamic West (eighth-fifteenth centuries), and IslHornAfr: Islam in the Horn of Africa. A comparative Literary Approach, held at the University of Copenhagen, 2015-2019), and a third one funded by the CSIC (Manuscritos fechados en al- 
Andalus: Repertorio y análisis). She has published two books related to the Islamic law on usury (El valor del tiempo. Doctrina jurídica y práctica de la usura (ribā) en el Occidente islámico medieval, Academia Scientiarum Fennica, 2016; El Kitāb al-ribā de 'Abd al-Malik b. Habīb (m. 238/852), CSIC, 2017), and several articles, some of them related to the Arabic and Islamic manuscripts produced in the Horn of Africa, such as "The Ajamization of Islam in Ethiopia through esoteric textual manifestations in two collections of Ethiopian Arabic manuscripts" (Islamic Africa 8, 2017).

Takao Ito (PhD, University of Munich) is Associate Professor in the Graduate School of Humanities at Kobe University, Japan. His research focuses on the social and cultural history of the premodern Mashriq (eastern Arab world), particularly Mamlūk and early Ottoman Egypt and Syria, and on post-classical Arabic historiography. Among his publications are "Al-Maqrīzī's Biography of Timūr" (Arabica 62, 2015), "Al-Suyūțī and Problems of the waqf" (in: Antonella Ghersetti, ed., Al-Suyūțī, a Polymath of the Mamlūk Period, Brill, 2016), “The Last Mamluk Princess, Her Endowment, and Her Family History" (Orient 54, 2019), "Careers and Activities of Mamluk Traders: Preliminary Prosopographical Research" (forthcoming), and "A Collection of Histories of the Mamluk Sultanate's Syrian Borderlands: Some Notes on MS Ahmet III 3057 (TSMK, Istanbul)" (forthcoming).

Maiko Noguchi (PhD, Ochanomizu University, Tokyo) is a postdoctoral Research Fellow of Japan Society for the Promotion of Science at the Institute for Advanced Studies on Asia, University of Tokyo. She has published articles on the history of the Almoravids and Berbers in the medieval period, such as "The bay'a and Legitimation of Almoravid Rule" (The Toyo Gakuho: The Journal of the Research Department of the Toyo Bunko 96, 2015), and "The Almoravids in the Maghrib in the First Half of the 12th Century: Examining the Governing System through Analysis of the Relationship between Governors and the Ulama, Sufis and Saints" (The world of Islam 88, 2017), in Japanese.

Abdenour Padillo-Saoud is a predoctoral fellow at the School of Arabic Studies (EEA), Spanish National Research Council (CSIC). Prior to earning a Master's degree in Arab and Hebrew Culture at the University of Granada in 2016, he earned his B.A. in Arabic and Islamic Studies at the same institution in 2015. From 2016 to 2017 Padillo-Saoud joined the Ibn Tufayl Foundation for Arabic Studies as a pre-doctoral researcher; there he worked on different projects related to the mobility of the Andalusis 'ulama' 'to the East during the Islamic period in the Iberian Peninsula. In addition to a research stay at the Université Abdelmalek Essaaâdi in Tetouan (Morocco) in 2014, he has taken several courses on digital humanities and published an article and several biographical entries for the third volume of the Alhadra journal. His research focuses on the historiography of the pre-modern Islamic world, while his $\mathrm{PhD}$ thesis deals with the impact of Andalusi intellectual activity on the Mamlūk historiography of the Bahrī period.

Mayte Penelas (PhD, Autónoma University of Madrid) is Tenured Scientist at the School of Arabic Studies, Spanish National Research Council (CSIC). Currently she is also the director of this research institute located in Granada. Her PhD thesis on the Arabic translation of the Orosius' Historiae adversus paganos (5th c.) made in early 10th-century al-Andalus resulted in the publication of this text (Kitāb Hurūšiyūš, CSIC - AECI, 2001) and a number of articles. She has also published several articles on the Christian Arabic texts contained in MS Raqqāda 2003/2. She 
has participated in six national research projects, and is currently co-director - along with Maribel Fierro (ILC, CSIC) - of the research project Local contexts and global dynamics: al-Andalus and the Maghreb in the Islamic East (AMOI) (FFI2016-78878-R AEI/FEDER, UE). She also participates in the EC Project Mediating Islam in the Digital Age. Present issues and past experiences of technological revolutions (MIDA) (H2020-MSCA-ITN-2018, no. 813547). She has been involved in the elaboration of the PUA database (www.eea.csic.es/pua), and participates in the Bibliotheca Maqriziana series of Brill, with the edition and translation of Al-Maqrīī's al-Habar 'an al-bašar, Vol. V, Section 6: The Greeks, Romans, Byzantines, Franks, and Goths (2020).

Iria Santás de Arcos (PhD, University of Salamanca). She currently teaches Arabic Language in the Faculty of Classical and Christian Literature, University San Dámaso of Madrid. She is a team member of the Research Project Local contexts and global dynamics: al-Andalus and the Maghreb in the Islamic East (FF12016-78878-R AEI / FEDER UE). Her research focuses on Andalusi $a d a b$, the history of food and nutrition in Islamic and Arabic societies, Christian Arabic Literature and the intellectual production of the Early Islamic West. Among her latest publications is "Ibn 'Abd Rabbihi. ¿Legitimador de la dinastía omeya? Cuestiones de poder en el Iqd al farīd” (in: V. Lamazou-Duplan, ed., Écritures du pouvoir, Ausonius, 2019).

Kentaro Sato (PhD, University of Tokyo) is associate professor of Oriental History at Hokkaido University, Japan. He specializes in the history of al-Maghrib and al-Andalus. He has published on various topics in this field and his publications include: "Yannayr and al-'Anșara: Seasonal Festivals in the Medieval Muslim West" (The Journal of Sophia Asian Studies 30, 2012), "Sufi Celebrations of Muhammad's Birthday (al-Mawlid al-Nabawī) and the Ulama's view on it in alAndalus and al-Maghrib, 1300-1400" (The Journal of Sophia Asian Studies 24, 2006), and "Slave Elites and the Șaqāliba in al-Andalus in the Umayyad Period" (in: T. Miura \& J.E. Philips, eds., Slave Elites in the Middle East and Africa, Kegan Paul, 2000). He is also co-editor of The Vellum Contract Documents in Morocco in the Sixteenth to Nineteenth Centuries (2 vols., Toyo Bunko, 2015, 2020), and author of a chapter on al-Andalus in History of Spain (Yamakawa, 2008 , in Japanese). He is currently collaborating on a translation project of the autobiography of Ibn Khaldūn, for which he was awarded "Prix Ibn Khaldoun" in 2016 by the Programme Med 21 at Tunis.

Khaoula Trad is a Research Associate within the ERC Project "Contemporary Bioethics and the History of the Unborn" and a PhD student working on "The Imagination of the Unborn in the Islamic West: Al-Maghrib and al-Andalus between the 12th and the 13th Centuries". She obtained her MA of Arabic and Hebrew cultures from the University of Granada in 2014 after receiving an Erasmus Mundus Al-Idrissi scholarship. She also holds a MA and a BA in Spanish literature and linguistics from the University of Manouba where she worked as a teacher of Spanish as foreign language between 2014 and 2016.

Juan Carlos Villaverde Amieva has a degree in Romance Philology from the University of Oviedo, where he is a professor of Arab and Islamic Studies. Interested in the relationships between Arabic and the Romance languages, he deals with the study of Aljamiado literature, the Romance language of al-Andalus, translations and Romance versions of Arabic scientific works, Arabisms in Romance and medieval Latin, as well as the history of Arab-Romance studies. Secretary of the journal Aljamía, he founded and directs the Seminario de Estudios Árabo- 
Románicos (SEAR) of the University of Oviedo and its editorial collections. He is co-author of Glosario de voces aljamiado-moriscas (Universidad de Oviedo, 1994; 2nd ed., 2015). Among his publications are "Towards the study of the Romance languages in the Kitāb al-Mustaiîn?" (in: C. Burnett, ed., Ibn Baklärish's Book of Simples, Oxford University Press, 2008), “Aljamiado reprobar 'someter a prueba”' (in: H. Döhla et al., Lenguas en diálogo, Iberoamericana Vervuert, 2008), “Recetarios médicos aljamiado-moriscos” (in: F. Gambin, ed., Alle radici dell'Europa, vol. II, SEID, 2010), "Los manuscritos aljamiado-moriscos: hallazgos, colecciones, inventarios y otras noticias” (in: Memoria de los moriscos, BNE, 2010), “Un papel de Francisco Antonio González sobre 'códices escritos en castellano con caracteres árabes' (Real Academia de la Historia, año 1816) y noticia de las copias modernas de Leyes de Moros” (in: R. Suárez and I. Ceballos, eds., Aljamías, Trea, 2012), and "Historia de Muça. Un relato aljamiado entre los descendientes de moriscos exiliados en Túnez" (Rivista di storia e letteratura religiosa 51, 2015). He is currently preparing a work under the title Farmacología árabe y lenguas romances.

Josef Ženka (PhD Charles University of Prague) is Assistant Professor of Islamic History at Charles University in Prague. In 2017-2018 he was a research fellow at the Annemarie-Schimmel-Kolleg "History and Society during the Mamluk Era (1250-1517)" at University of Bonn where he worked on autograph manuscripts of Andalusi immigrants to the Mamlūk sultanate. His research interests focus on the manuscript and documentary culture of Nașrid Granada with a special focus on scribal and legal practice of notaries-scribes and Granadan scholars living in the Mamlūk sultanate. His recent works include a study "A Manuscript of the Last Sul$\tan$ of al-Andalus and the Fate of the Royal Library of the Nașrid Sultans at the Alhambra" Uournal of Islamic Manuscripts 9, 2018). His second line of research examines the History of Orientalism. In this framework, he edited two volume autobiography of Czech-American specialist in Andalusi and Romance literatures A. R. Nykl: Padesát let cest jazykozpytce a filosofa (Univerzita Karlova - Národní muzeum, 2016) and Poznámky k revolučni akci v Chicagu, 1914-1918 (Univerzita Karlova - Národní muzeum, 2017). He is the author of the Czech translation of Nubdhat al'Așr fĩ Akhbār Mulūk Banī Nașr and Historia de los Reyes Moros de Granada of Hernando de Baeza published together as Pád Granady a Zánik al-Andalusu (Argo, 2011). 